\title{
NEW TECHNICAL SOLUTIONS IN UPGRADING HISTORIC BUILDING TO STANDARD OF NEARLY ZERO-ENERGY BUILDING. EXAMPLE OF TENEMENT HOUSE IN POZNAŃ
}

\author{
NOWE ROZWIAZANIA TECHNICZNE W DOSTOSOWANIU ZABYTKU \\ DO STANDARDU BUDYNKU NIEMAL ZEROENERGETYCZNEGO \\ NA PRZYKŁADZIE KAMIENICY W POZNANIU
}

\section{Sławomir Rosolski}

Dr hab. inż. arch. profesor PP

Author's Orcid number: 0000-0001-9529-0423

Poznań University of Technology, Poland

Faculty of Architecture

\begin{abstract}
This article aims at discussing the issue of relation between an existing historic building and modern technology, which may lead to upgrading the historic building to parameters of a nearly zeroenergy building. It focuses on the possibility to adjust the facility to contemporary forms of using without considerable prejudice to its historic substance and identity, on contrary, with due respect for the old tissue in the context of NZEB parametrisation. The adjustment refers to innovative solutions allowing upgrade of the building by using the most effective technologies based on renewable energy, improved power efficiency of the structure, technical equipment, exterior and interior cladding and meeting requirements connected with minimum global cost in the life cycle assessment of the building.
\end{abstract}

Key words: nearly zero-energy building, NZEB, historic building, new technologies, renovation, life cycle assessment (LCA).

\section{STRESZCZENIE}

W artykule przedstawiono badania dotyczące określenia związku pomiędzy istniejącym zabytkiem a współczesną technologią, co może prowadzić do przystosowania zabytku do parametrów budynku niemal zeroenergetycznego. Artykuł zwraca uwage na możliwość przystosowania obiektu do współczesnych form użytkowania bez znaczącego uszczerbku dla jego substancji zabytkowej i tożsamości oraz poszanowania starej tkanki w kontekście parametryzacji budownictwa niemal zeroenergetycznego, wykorzystując innowacyjne rozwiązania umożliwiające poprawę standardu budynku poprzez zastosowanie najefektywniejszych technologii wykorzystujących energie odnawialną, poprawę efektywności energetycznej struktur budowlanych, wyposażenie techniczne, obudowę zewnętrzną i wewnętrzną oraz spełnienie wymogów związanych z minimalnym kosztem globalnym w cyklu życia budynku.

Słowa kluczowe: budynek niemal zeroenergetyczny, zabytek, nowe technologie, renowacja, cykl życia budynku. 


\section{INTRODUCTION}

The value of historic buildings goes without saying. These are places that accumulate the memory of past events, human achievements, technical innovations and aesthetic creations made by our ancestors. However, the past is also important as it is the foundation for the present and future. This brings the necessity of discussion on the possibility of upgrading the facility to contemporary forms of using without considerable prejudice to its historic substance and identity. Respect for the old tissue in the context of NZEB parametrisation is possible. The adjustment refers to innovative solutions allowing upgrade of the building by using the most effective technologies based on renewable energy, improved power efficiency of the structure, technical equipment, exterior and interior coating and meeting requirements connected with minimum global cost in the life cycle assessment (LCA) of the building.

The above thesis has already been proven. The historic substance has been successfully combined with the latest achievements of science and technology in the $15^{\text {th }}$ century tenement house at ul. Wroniecka 23 in Poznań. It is an element of the urban complex of the Old Town. The conducted research has revealed data about the object, changes, reconstructions and destructions the building has gone through, including this most severe damage it suffered during the second world war. Then the tenement house was left forgotten, neglected, covered with many layers of five hundred years of its existence. Its history was deeply hidden in the basement and revealed during research works. Today, this centuries-old house is a renovated, addressed to new functions and nearly zeroenergy building. It is a science-research-didactic-implementation unit with interactive art gallery, streaming room and recording studio in situ. It is also headquarters for studios of architecture, urban planning, design and fashion.

\section{NEARLY ZERO-ENERGY BUILDING (NZEB)}

The term "low energy building" appeared for the first time in 1977 (Amory Lovins ${ }^{1}$ ); first buildings of that type were raised in Korsgaard, Copenhagen (in 1977), Shick, Illions and Elmorth, Stockholm.

Directive 2010/31/EU of the European Parliament and of the Council of 19 May 2010 on the energy performance of building, defines the NZEB in the following words: "nearly zero-energy building' means a building that has a very high energy performance (...). The nearly zero or very low amount of energy required should be covered to a very significant extent by energy from renewable sources, including energy from renewable sources produced on-site or nearby."

For the sake of implementations of requirements stipulated in the amended Directive on the energy performance of building, it is enough to analyse the following types of buildings from the point of view of their energy demand for operation:

- SEB - buildings meeting minimum energy requirements stipulated in national provisions (energy buildings regulation);

- LEB (low energy buildings);

- VLEB (very low energy buildings, passive buildings);

- ZEB (zero energy buildings) and +ZEB;

- NZEB (nearly zero-energy buildings, close to zero energy buildings).

Zero energy buildings may also be called zero emission buildings, i.e. zero carbon footprint buildings in operation.

Nearly zero-energy buildings (NZEB):

- $\quad$ NZEB $=$ LEB + renewable energy (transitional period)

- NZEB $=$ VLEB + renewable energy (eventually)

\footnotetext{
${ }^{1}$ Amory Lovins (born in 1947 in Washington) - American physicist and ecologist. Author of 30 books on sustainable development. In the 70s he was a member of the British branch of the ecological organisation Friends of the Earth. In 1982 together with his wife, Lovins founded an organisation promoting energy efficiency and renewable energy sources. In 1983 Amory and Hunter Lovins were awarded by Right Livelihood „for pioneers' input in promoting green energy”.
} 
NZEB should also be perceived as multi-criteria issue, as presented on Fig.1.

Fig. 1. NZEB as multi-criteria issue. Source: Szczechowiak. E., 2013

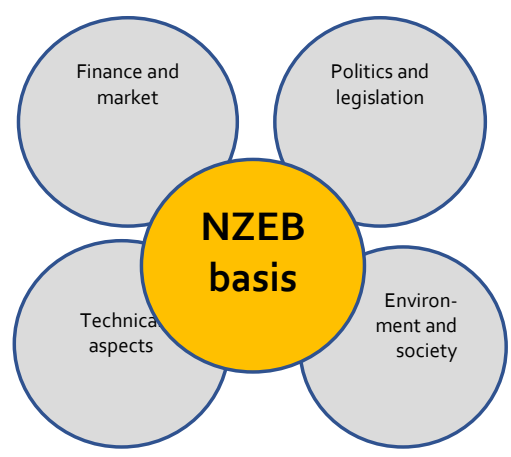

The definition of the nearly zero-energy building refers to delivered and exported energy, the definition of which is stipulated in accordance with the amended Directive (EPBD) and the norm EN 15603:2008:

- Delivered energy (EN 15603:2008) - energy, expressed per energy carrier, supplied to the technical building systems through the system boundary, to satisfy the uses taken into account (e.g. heating, cooling, ventilation, domestic hot water, lighting, appliances etc.) or to produce electricity.

- Exported energy (EN 15603:2008) - energy, expressed per energy carrier, delivered by the technical building systems through the system boundary and used outside the system boundary.

- Net delivered energy (c) - delivered minus exported energy, both expressed per energy carrier.

- Primary energy (amended Directive (EPBD)) - energy from renewable and non-renewable sources which has not undergone any conversion or transformation process.

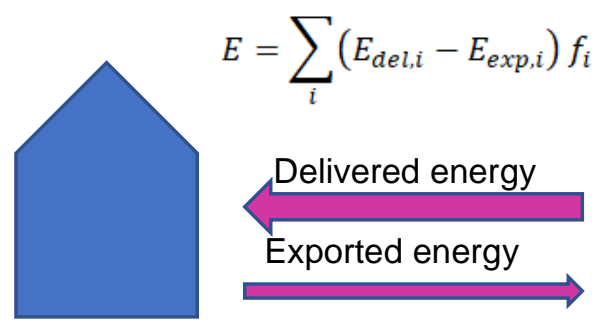

Fig. 2 Net delivered energy is a difference between energy delivered to the building $E_{d e l, i}$ and energy exported to the system Eexp,i, respecting any energy carrier. Primary energy $E$ is defined as a product of net delivered energy and primary energy input ratio $f i$ (the same ratios refer to the energy delivered to the building and exported to the system). Source: own material

Definitions of a nearly zero-energy building (NZEB) may be referred to a zero-energy building (ZEB). ZEB is a building in which energy consumption during the year, converted into final energy (delivered and sold) equals zero (site ZEB) or, as effect of conversion into primary energy during the year equals $0 \mathrm{kWh} /\left(\mathrm{m}^{2} \mathrm{a}\right)$, (source ZEB), as shown on Fig. 3 . In case the technical system of the building produces and exports more energy than the building uses, such building is classified as +ZEB (Fig. 4.). According to the amended Directive (EPBD) and the norm EN 15603:2008, in the nearly zero-energy building (NZEB), the balance of yearly settlement of delivered primary ener- 
gy and sold (exported) primary energy is plus zero, i.e. the building consumes more primary energy than it sells. The method of balancing primary energy in NZEB is presented on Fig. 5.

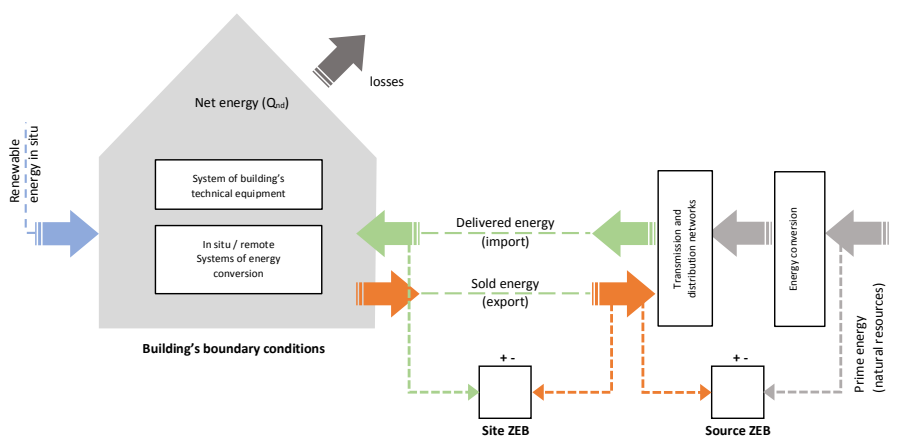

Fig. 3. Balancing ZEB and NZEB. Mańkowski S., Szczechowiak E. 2013

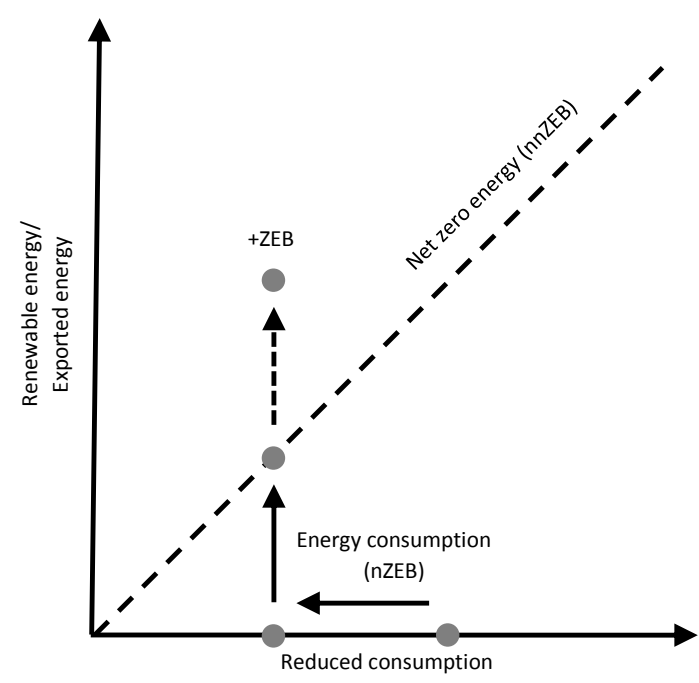

Fig. 4. Balancing NZEB, ZEB and + ZEB. Mańkowski S., Szczechowiak E., 2013

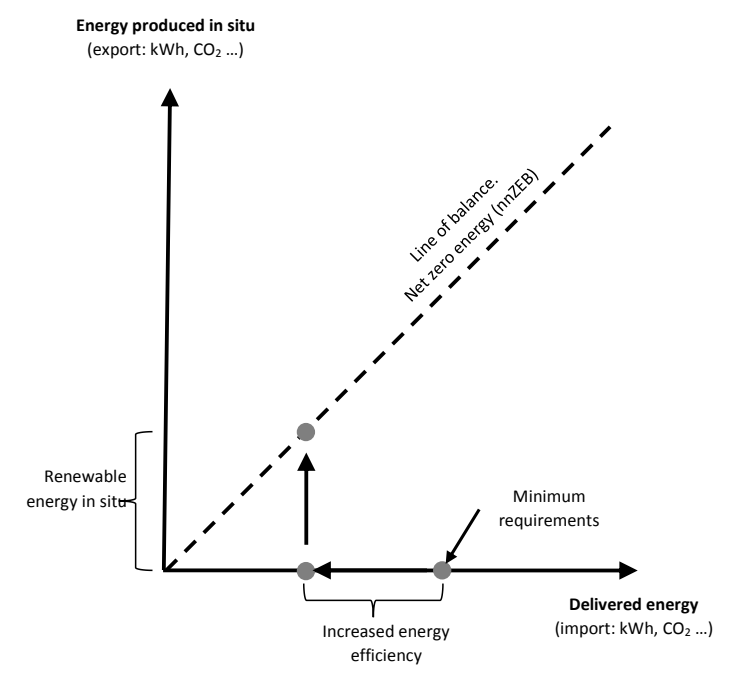

Fig. 5 Balancing NZEB. Mańkowski S., Szczechowiak E., 2013

The quoted notions, directives, definitions and terms regarding NZEB are prepared for new, modern buildings or, to some degree, for modernized facilities, which are later settled in terms of their energy balance. As far as the Author knows, they do not refer to historic substance. Therefore, the Authors raises a question, which he answers hereunder: can a historic building be NZEB? Can an NZEB be a historic building? (Rosolski S., 2018)

\section{NEARLY ZERO ENERGY HISTORIC BUILDING \\ - TENEMENT HOUSE AT WRONIECKA 23 IN POZNAŃ, POLAND}

The tenement house at Wroniecka 23 in Poznań is an element of the urban complex of the Old Town. Although it is neither a grade A historic building, nor spectacular or visited by crowds of tourists, it does not play a key role in identifying the city either, yet it contains unquestionable valuable historic substance revealed in conducted research. The conducted query provided data about the facility and showed dynamic transformations the building experienced, including destruction during the second world war. In 1959, Henryk Kondziela collected materials regarding the house. They proved significant changes in geometry of the roof, form of the front façade, shape of windows and many other components which were styled in the effort of restoring the Old Town after the war. The 
tenement house at Wroniecka 23 became a component of this process; its authenticity was buried deep down in the basement, in selected elements revealed during research and documentation works. In the process of recognising, shaping and defining the scale of renovation the primary intentions of constructors were searched for. Layers of consecutive epochs were diagnosed and the structure and relations between components were hierarchised. Specialists analysed a multidirectional strategy to define the durable and solid security for the facility.

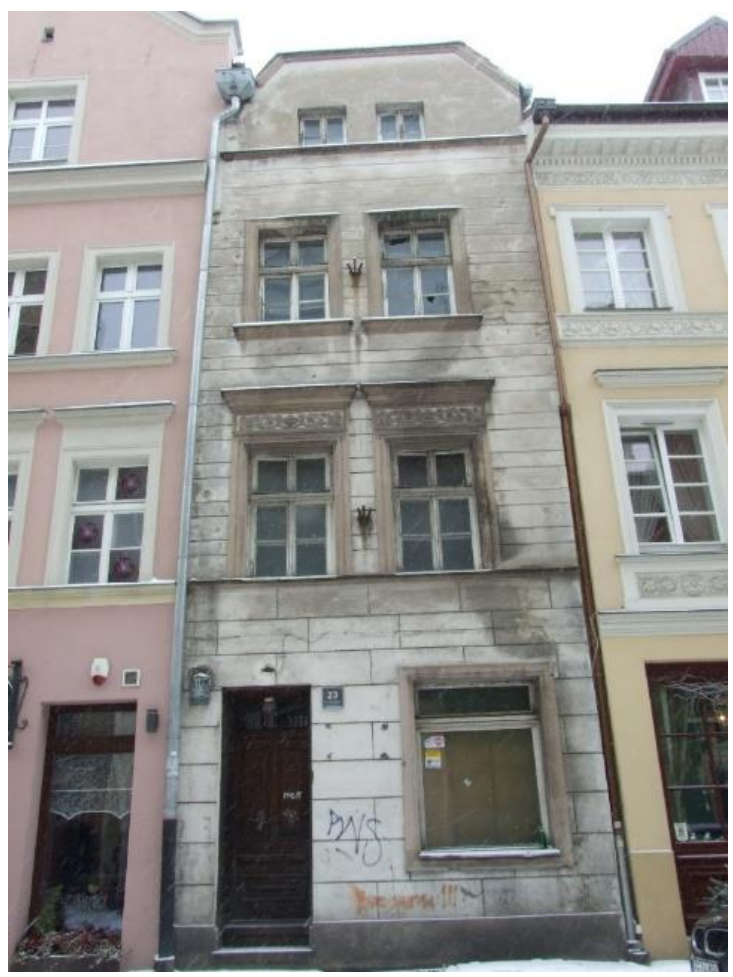

Front elevation / Elewacja frontowa

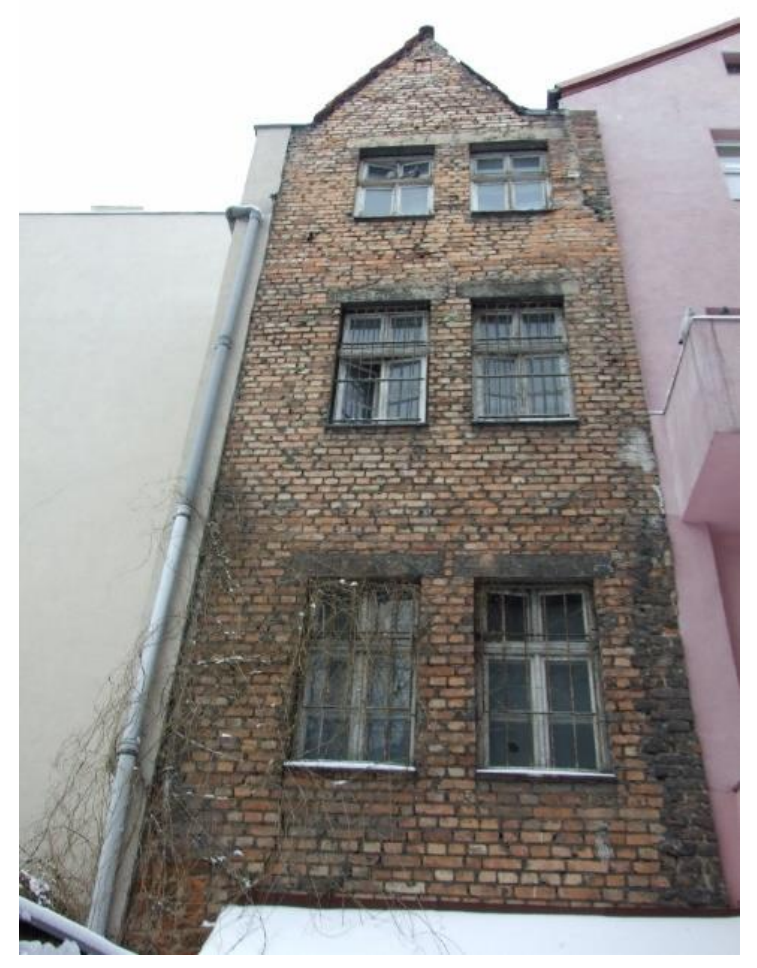

Back elevation / Elewacja tylna

Fig. 6. The tenement house before renovation. Source: Archives of APPSR Architekt Rys. 6. Kamienica przed renowacją. Źródło: Archiwum APPSR Architekt.

All this led to taking actions aiming at protection and exposition of authenticity of the historic substance. The new splendour was brought back by uncovering and reading faces of walls inside the building and, in particular, perceiving the front façade of the first and second floor as a witness. Therefore, the façade's design preserves the first and second floor with the distinctive, modern sketch of the ground floor and attic. The line of the attic was shaped in the 1960s but now it has gained a new line with elliptical, spatial form which intentionally cuts through the modern cornice and thus, underlines the context of relating past to future. In order to highlight the adopted solutions, the elevation was designed as monochromatic in structure, material and colour of light quartz. The building is also an example of successful elevation modernisation in terms of outdoor and indoor thermal insulation.

From the technical point of view, the house has been transformed into NZEB, which is a pioneer approach to the historic building, cutting edge for the system that technically protects the historic substance better than ever before. All research and inventory works have led to protecting and unveiling the historic value of the place, which is visible both inside and outside the house. At the same time, the building is now adapted to new functions and solutions connected with energy saving and environmental protection. 
Approaching the historic facility in the aspect of contemporary requirements regarding lowering energy consumption and environmental protection was possible thanks to:

- New methods of research and documentation

- New materials and technologies

- New technical solutions based on renewable sources of energy.

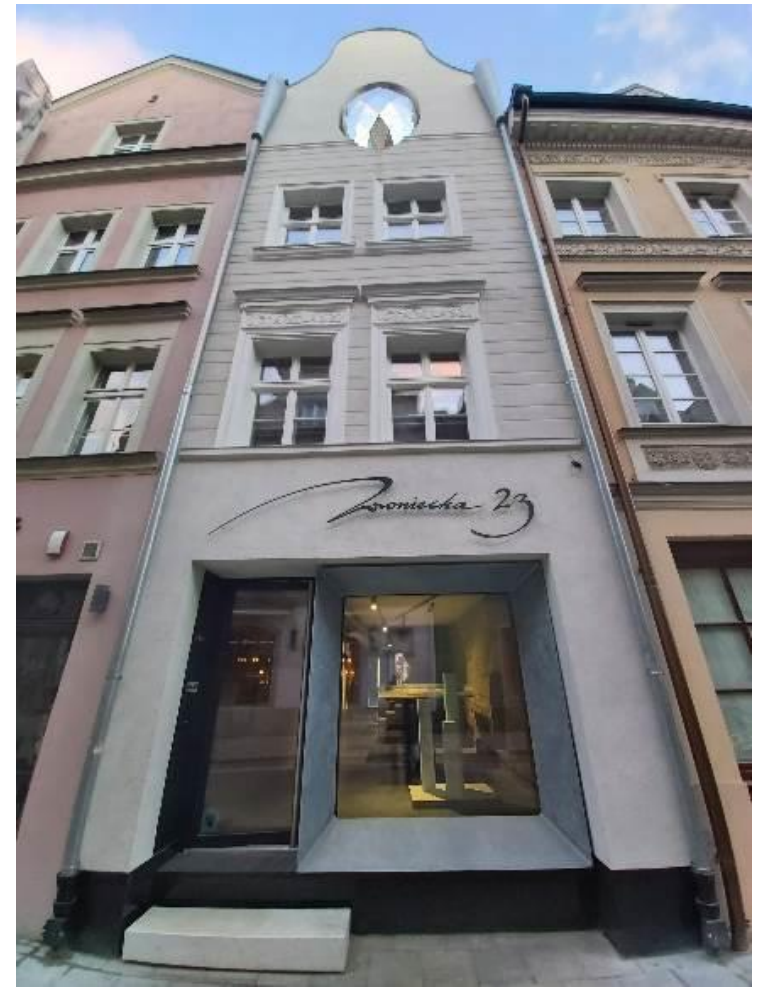

Front elevation / Elewacja frontowa

Fig. 7. The tenement house after renovation. Source: Archives of APPSR Architekt Rys. 7. Kamienica po renowacji. Żródło: Archiwum APPSR Architekt
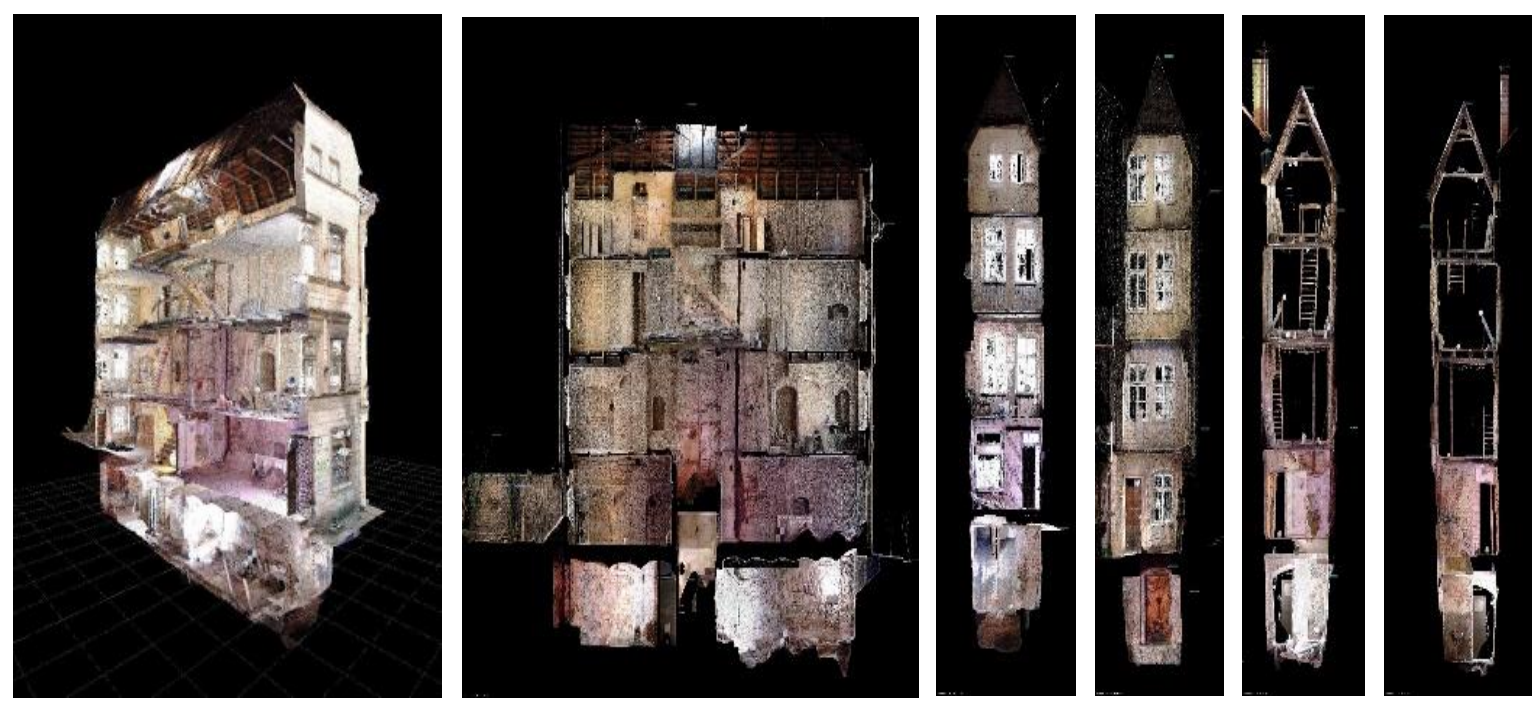

Fig. 8. Laser scanning, mapping, 3D scanning. Source: Archives of APPSR Architekt Rys. 8. Scanning laserowy, mapping, skanowanie 3D. Żródło: Archiwum APPSR Architekt 
Upgrading the facility to the standard of NZEB has been achieved on the basis of an algorithm of designing nearly zero-energy historic buildings. The algorithm is presented on Fig. 4 .

Fig. 9. Algorithm of designing NZEB (where TC is thermal comfort, IAQ is indoor air quality, EU is usable energy for heating and ventilation, HVAC is heating, ventilation and air conditioning, EP - prime energy, EPmax is the prime energy ratio defined for optimal global cost for a given category of buildings). Source: own materials, EKIR 2018.

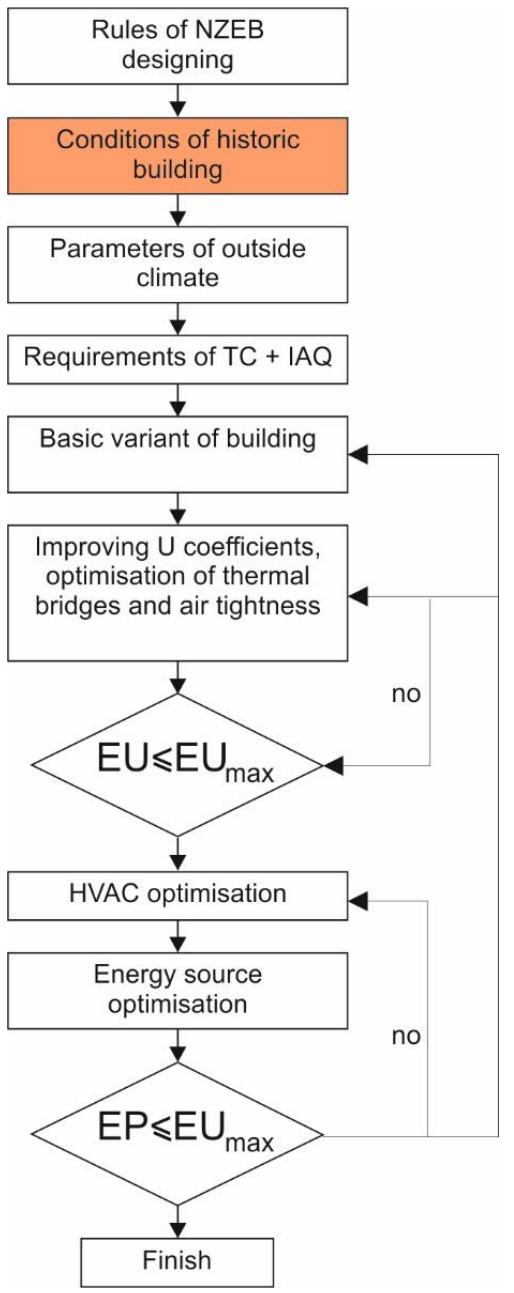

Thanks to the innovative approach to the renovation, the tenement house at Wroniecka 23 in Poznań has obtained parameters defined for contemporary facilities and met requirements of technical conditions valid in 2021. Selected solutions applied in the building to achieve the status of NZEB include such elements as:

- Upgraded thermal protection of external partitions:

- Thermal insulation of the back elevation from outside $-\mathrm{U}=0.15 \mathrm{~W} / \mathrm{m}^{2} \mathrm{~K}$

- Thermal insulation of the front elevation from inside - $U=0.15 \mathrm{~W} / \mathrm{m}^{2} \mathrm{~K}$

- Thermal insulation of the roof - U=0.09 W/m² K

- Upgraded air tightness of the building (minimising waste through infiltration) - n50 $=0.61 / h$ :

- Outside windows in layer-sealing and tight-fitting installation

- Wooden 5-pane casement windows - U $=0.8 \mathrm{~W} / \mathrm{m}^{2} \mathrm{~K}$

- Wooden single-frame, insulated glass, 3-pane windows $=\mathrm{U}=0.8 \mathrm{~W} / \mathrm{m}^{2} \mathrm{~K}$

- Aluminium window display, 3-pane - $\mathrm{U}=0.8 \mathrm{~W} / \mathrm{m}^{2} \mathrm{~K}$

- 3-pane roof windows - $\mathrm{U}=0.8 \mathrm{~W} / \mathrm{m}^{2} \mathrm{~K}$

- Outside integrated windows - panes protecting against solar radiation 
- Air outlet on the roof located far away from air inlet

- Decentralization of ventilation / air conditioning systems - two recuperators divided into storey sections

- Heat recovery from outlet air - mechanical ventilation with recuperation

- Thermally activated ceilings - basic system of thermal stabilisation in winter and summer (integrated heating / cooling system in the reinforced concrete ceiling)

- Reinforced concrete stairs - energetic accumulation

- Staircase - natural ventilation of the building, convection chimney

- Heat pump, air-water

- Photovoltaic solar collectors PV 4KWh to support power supplies (roof)

- Using condensate from AHU to water plants inside the building

- Air conditioners installed for extreme operation conditions

- Fully automated, energy self-efficient skylights which enable facility airing in transition periods

- Ventilation membrane - natural airing of foundations to drain humidity in a non-invasive way

- Sensors of humidity, temperature, $\mathrm{CO} 2$, presence of volatile organic compounds, suspended dusts PM10 and PM 2.5 to control and conduct research on air quality

- Integrated data system to control building's parameters

- An attempt to apply surface which, when exposed to light, decreases the cost of illumination exploitation (in accordance with laboratory and implementation works).

Moreover, what draws attention is the integrated system of technical equipment in the building and its exposition with historic substance as the background:

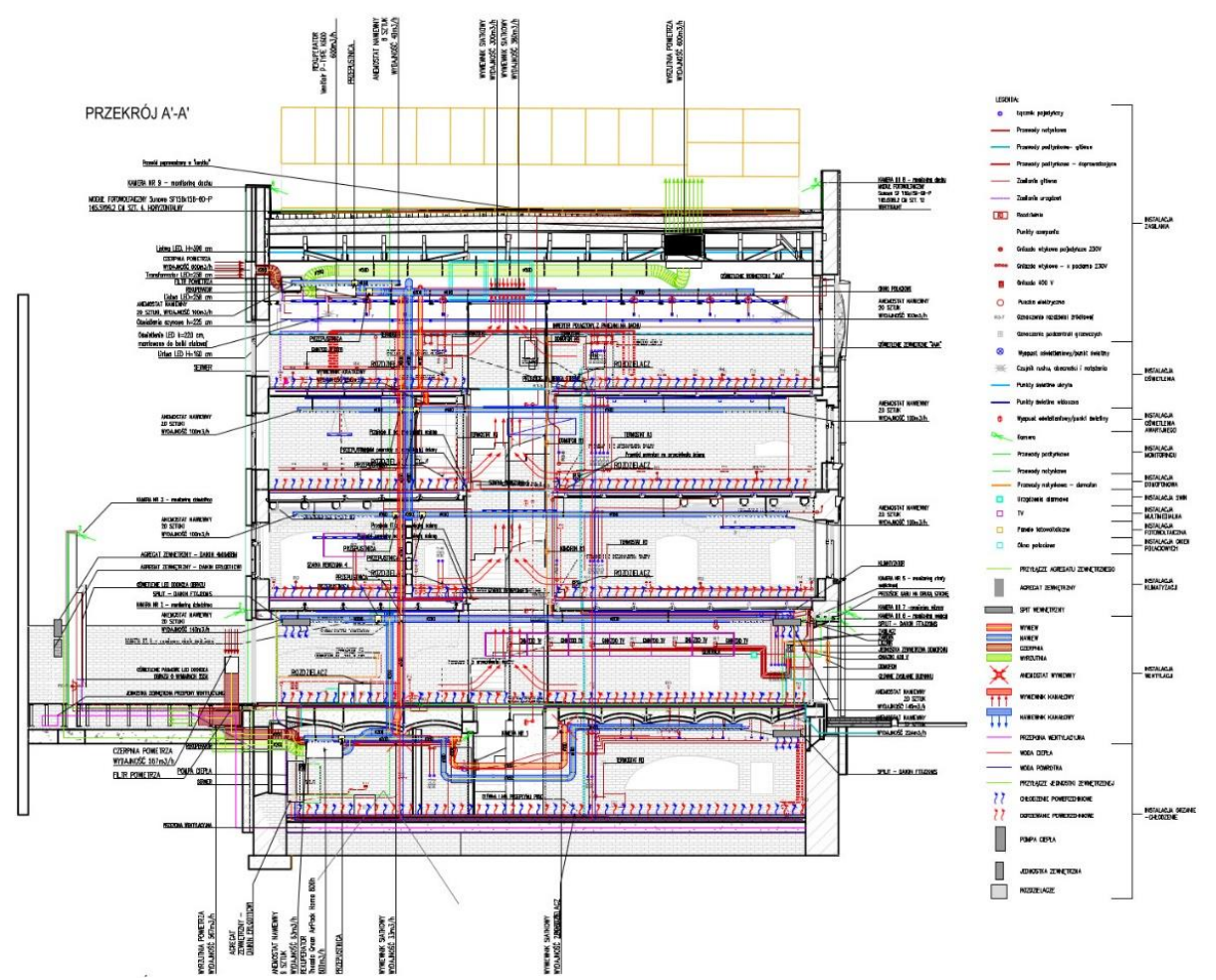

Fig. 10. Integrated system of technical equipment at Wroniecka 23. Source: Archives of APP SR Architekt 

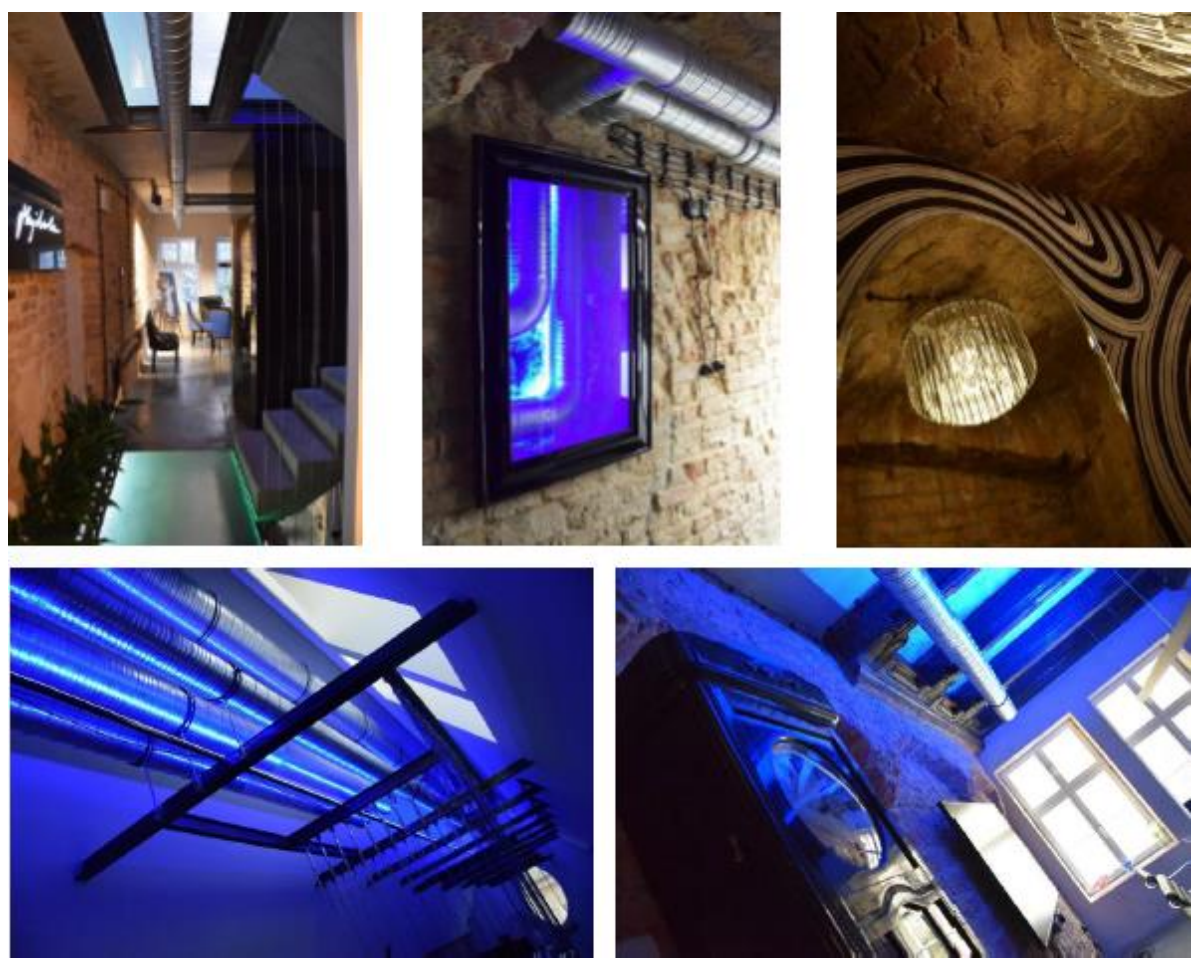

Fig. 11. The interior of the tenement house at Wroniecka 23. Source: Archives of APP SR Architekt Rys. 11. Wnętrze kamienicy przy ul. Wronieckiej 23. Żródło: Archiwum APP SR Architekt

Respective approach to historic conditions of the place and technical innovations implemented simultaneously have resulted in obtaining parameters defined for contemporary facilities and meeting technical requirements stipulated in $2021^{2}$.

Energy parameters of the building (balancing includes heating, cooling and ventilation, hot water and in-built lighting):

- Yearly demand for final energy:

- Revitalised building: 17.85-18.95 kWh/(m²a)

- Yearly demand for non-renewable prime energy:

- Revitalised building: 53.5-56.8 kWh/(m²a)

- Share of renewable energy in a year (PV collectors): $86-91 \%$

Energy performance of the tenement house presents data far better than stipulated in WT requirements stipulated for contemporary buildings. Yearly demand for non-renewable prime energy (energy from the grid $+\mathrm{PV}$ collectors) is:

- Revitalised building: $\mathrm{EP}=4,5-7,9 \mathrm{kWh} /\left(\mathrm{m}^{2} \mathrm{a}\right)$

- Technical requirements 2019/2021: EP $=95,0 \mathrm{kWh} /\left(\mathrm{m}^{2} \mathrm{a}\right)$

- Share of renewable energy: 87-92\% (PV collectors + heat pump)

Comparing final energy and $\mathrm{CO} 2$ emission in the revitalised building (RB) in 2020 is presented in the Table below (Tab. 1).

\footnotetext{
${ }^{2}$ Since 2021 , the $U$ coefficient may not exceed $0.2 \mathrm{~W} / \mathrm{m}^{2} \mathrm{~K}$; windows and balcony door: from $1.1 \mathrm{~W} / \mathrm{m}^{2} \mathrm{~K}$ to $0.9 \mathrm{~W} / \mathrm{m}^{2} \mathrm{~K}$; roof windows: from $1.3 \mathrm{~W} / \mathrm{m}^{2} \mathrm{~K}$ to $1.1 \mathrm{~W} / \mathrm{m}^{2} \mathrm{~K}$; Ep ratio (which stipulates building's maximum yearly demand on non-renewable prime energy consumption needed for ventilation, cooling, hot water and lighting). Since 2021 this ratio has been lowered to the minimum of $70 \mathrm{kWh} / \mathrm{m}^{2} / \mathrm{year}$.
} 
Table 1. Final energy and CO2 emission in the revitalised building (RB) in 2020. Source: own materials, EKIR 2018.

\begin{tabular}{|c|c|c|c|c|}
\hline No. & Description & $\begin{array}{l}\text { EP requirements } \\
\text { acc. to TW2021 }\end{array}$ & $\begin{array}{c}\text { Final energy } \\
\text { consumption } \\
\text { acc. to TW2021 }\end{array}$ & $\begin{array}{c}\text { Final energy } \\
\text { consumption in } \\
\text { historic building }\end{array}$ \\
\hline 1. & $\begin{array}{l}\text { Heating, cooling, ventilation, } \\
\text { hot water }\left[\mathrm{kWh} /\left(\mathrm{m}^{2} \mathrm{a}\right)\right]\end{array}$ & $\begin{array}{c}45+ \\
25\end{array}$ & 49.5 & $7.85-8.95$ \\
\hline 2. & In-built lighting $\left[\mathrm{kWh} /\left(\mathrm{m}^{2} \mathrm{a}\right)\right]$ & 25 & 8.3 & 10.0 \\
\hline 3. & Total $\left[\mathrm{kWh} /\left(\mathrm{m}^{2} \mathrm{a}\right)\right]$ & 95.0 & 57.8 & $17.85-18.95$ \\
\hline 4. & $\begin{array}{ll}\text { Own production } & \text { PV } \\
{\left[\mathrm{kWh} /\left(\mathrm{m}^{2} \mathrm{a}\right)\right]}\end{array}$ & & & 16.8 \\
\hline 5. & $\begin{array}{l}\text { Energy consumption from grid } \\
\text { in } R B\left[k W h /\left(m^{2} a\right)\right]\end{array}$ & & & $1.55-2.65$ \\
\hline 6. & CO2 emission $\left[\mathrm{kgCO} 2 /\left(\mathrm{m}^{2} \mathrm{a}\right)\right]$ & & 24.6 & $1.28-2.19$ \\
\hline
\end{tabular}

That is how the historic tenement house at Wroniecka 23 has achieved results which exceed requirements:

- Share of renewable energy: $87-92 \%$

- $\mathrm{CO} 2$ emission $-5 \%$ of standard!

\section{SUMMARY}

The tenement house at Wroniecka 23 in Poznań is a historic place that has welcomed contemporary achievements of new technologies and become a science-didactic-research-implementation unit. Interaction, implementation and searching for synergy of actions at numerous fields of technical knowledge focuses on relation of past (as a historic building) and future (as solutions based on new technologies).

Wroniecka 23 is a historic background, component, limitation, creation and innovative approach for new technologies which aim at improving durability and protecting the historic substance in a way that is more effective than ever before.

The house helps to define the relation between its historic value and significance of new technologies in the process of adapting the historic building to requirements stipulated for contemporary facilities with low energy consumption. This can be done without prejudice to the building itself and with due respect to its history.

New technologies have served as tools to examine and diagnose the historic substance of the place. They have also provided innovative solutions providing upgrade of the building by using the most effective technologies based on renewable energy, improved power efficiency of the structure, technical equipment, exterior and interior coating and meeting requirements connected with minimum global cost in the life cycle assessment (LCA) of the building. In order to illustrate that, there is a system of monitoring and automatic management of the facility. The systems monitor values of important environmental parameters and installation status, integrate technological equipment, control energy consumption and production; they also register, analyse and present the data.

Wroniecka 23 has made an attempt and proved that it is possible to adjust a historic building to the standard of NZEB. At present, this place is way ahead of Polish requirements regarding technical conditions after 2020. The requirements for 2021 equal $95.0 \mathrm{kWh}\left(\mathrm{m}^{2} \mathrm{a}\right)$ whereas results obtained after renovation and installation of PV collectors equal $4.54-7.89 \mathrm{kWh}\left(\mathrm{m}^{2} \mathrm{a}\right)$. This result is by ca. $92-95 \%$ better than the required value. 


\section{NOWE ROZWIAZANIA TECHNICZNE W DOSTOSOWANIU ZABYTKU DO STANDARDU BUDYNKU NIEMAL ZEROENERGETYCZNEGO NA PRZYKŁADZIE KAMIENICY W POZNANIU}

\section{WPROWADZENIE}

Wartość obiektów zabytkowych jest bezsporna. To miejsca, które akumulują w sobie pamięć zdarzeń, ludzkich dokonań, osiągnięć technicznych i estetycznych kreacji powstających za sprawą naszych przodków. Przeszłość jest jednak istotna także dlatego, że stanowi fundament teraźniejszości i przyszłości. Stąd potrzeba poruszenia kwestii możliwości przystosowania obiektu do współczesnych form użytkowania bez znaczącego uszczerbku dla jego substancji zabytkowej i tożsamości. Możliwe jest poszanowanie starej tkanki w kontekście parametryzacji budownictwa niemal zeroenergetycznego przy jednoczesnym wykorzystaniu innowacyjnych rozwiązań umożliwiających poprawę standardu budynku poprzez zastosowanie najefektywniejszych technologii wykorzystujących energię odnawialną, poprawę efektywności energetycznej struktur budowlanych, wyposażenie techniczne, obudowę zewnętrzną i wewnętrzną oraz spełnienie wymogów związanych z minimalnym kosztem globalnym w cyklu życia budynku.

Dowodem na to, że można połączyć substancję zabytkową z najnowszymi osiągnięciami nauki i technologii jest XV-wieczna kamienica nr 23 przy ulicy Wronieckiej w Poznaniu, stanowiąca element zespołu urbanistycznego staromiejskiej części miasta. Przeprowadzone badania ujawniły dane o obiekcie, pokazując zmiany, przebudowy i zniszczenia, również te doświadczone w okresie II wojny światowej i później. Budynek został na wiele lat zapomniany, zaniedbany, przykryty nawarstwieniami powstałymi na przestrzeni minionych epok. Jego historia została ukryta w podziemnej kondygnacji i odsłonięta dopiero w trakcie prac badawczych. Dziś ten kilkusetletni, odrestaurowany i powołany do nowych funkcji obiekt jest budynkiem niemal zeroenergetycznym. Jest też nowoczesną jednostką naukowo-badawczo-dydaktyczno-wdrożeniową, posiadającą galerię interaktywną, salę streamingową oraz studio nagrań in situ. Znajduje się tu także siedziba pracowni architektury, urbanistyki, wzornictwa i mody.

\section{BUDYNEK NIEMAL ZEROENERGETYCZNY (NZEB)}

Sformułowanie dotyczące pojęcia „, budynek niskoenergetyczny” ( energooszczędny, low energy house) pojawiło się w 1977 roku (Amory Lovins ${ }^{3}$ ), natomiast pierwsze takie budynki powstały w Korsgaard- Kopenhaga ( 1977rok), Shick- Illions, Elmorth- Stockholm.

Dyrektywa 2010/31/ UE Parlamentu Europejskiego z dnia 19 maja 2010r. w sprawie charakterystyki energetycznej budynków definiuje budynek NZEB tymi słowami: „budynek o niemal zerowym zużyciu energii- oznacza budynek o bardzo wysokiej charakterystyce energetycznej (...). Niemal zerowa lub bardzo niska ilość wymaganej energii powinna pochodzić w bardzo wysokim stopniu z energii ze źródeł odnawialnych, w tym energii ze źródeł odnawialnych wytwarzanej na miejscu lub w pobliżu”.

Na potrzeby realizacji wymagań znowelizowanej Dyrektywy o charakterze energetycznym budynków wystarczy przeanalizować następujące rodzaje budynków, z punktu widzenia zapotrzebowania na energię dla ich eksploatacji:

- budynki spełniające minimalne wymagania energetyczne określone w przepisach krajowych SEB (energy buildings regulation),

- budynki niskoenergetyczne - LEB (low energy buildings),

\footnotetext{
${ }^{3}$ Amory Lovins (ur. 1947 w Waszyngtonie) - amerykański fizyk i ekolog. Autor ok. 30 książek poświęconych problematyce zrównoważonego rozwoju. W latach 70. działał w brytyjskim oddziale organizacji ekologicznej Friends of the Earth. W 1982 wraz z żoną założyli organizację zajmującą się promowaniem efektywności energetycznej i odnawialnych źródeł energii. W 1983 Amory i Hunter Lovins otrzymali nagrodę Right Livelihood „za pionierski wkład w propagowanie zielonej energii".
} 
- budynki ultra- niskoenergetyczne (pasywne) - VLEB ( very low energy buildings),

- budynki zero- energetyczne - ZEB oraz plus energetyczne + ZEB

- budynki niemal zero energetyczne - nZEB ( close to zero energy buildings, nearly zero energy buildings).

Budynki zeroenergetyczne można również nazywać budynkami zero- emisyjnymi, czyli o zerowym śladzie węglowym w czasie eksploatacji.

Budynki niemal zero energetyczne (nZEB):

- $\quad$ nZEB $=$ LEB + Energia odnawialna (okres przejściowy),

- $\quad \mathrm{nZEB}=\mathrm{VLEB}+$ Energia odnawialna (docelowo).

Budynki NZEB należy również postrzegać jako zagadnienie wielokryterialne, jak ukazano na rys. 12.

Rys. 12. Budynek nZeb jako zagadnienie wielokryterialne. Źródło: Szczechowiak. E., 2013

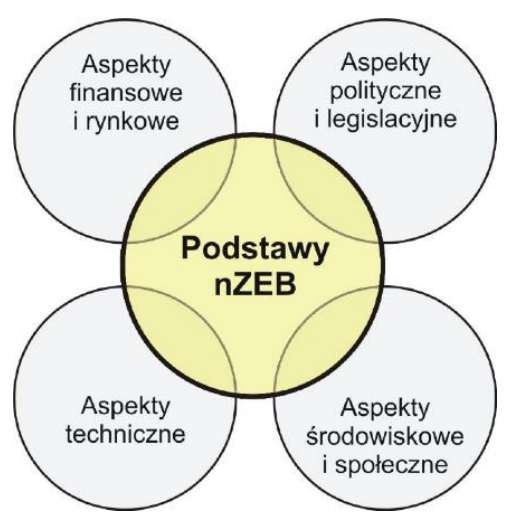

Definicja budynku niemal zeroenergetycznego odnosi się do energii dostarczonej i wyeksportowanej, których definicje zostały określone zgodnie z nowelizacją dyrektywy EPBD i normą EN 15603:2008:

- Energia dostarczona (EN 15603: 2008) - energia odniesiona do danego nośnika energii, dostarczana do systemów technicznych budynku spoza granicy bilansowej, niezbędna do zaspokojenia potrzeb (np. ogrzewania, chłodzenia, wentylacji, przygotowania ciepłej wody, oświetlenia, urządzeń itp.) lub do produkcji energii elektrycznej.

- Energia wyeksportowana (EN 15603: 2008) - energia odniesiona do danego nośnika energii, dostarczana przez systemy techniczne budynku poza granicę bilansową i zużywana poza nią.

- Energia dostarczona netto (EN 15603: 2008) - różnica pomiędzy energią dostarczoną a wyeksportowaną wyrażonych w odniesieniu do nośnika energii.

- Energia pierwotna (nowelizacja dyrektywy EPBD) - energia ze źródeł odnawialnych i nieodnawialnych, która nie została poddana żadnemu procesowi przemiany lub transformacji.

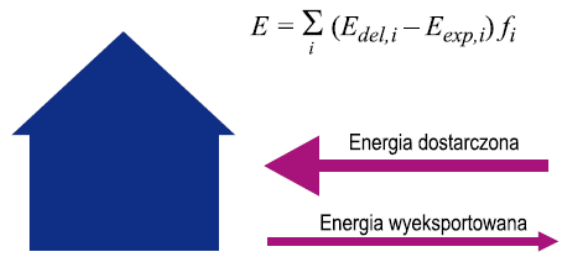

Rys. 13. Energia dostarczona netto jest różnicą pomiędzy energią dostarczaną do budynku Edel,i a energią wyeksportowaną do systemu Eexp,i, uwzględniająca każdy nośnik energii. Energia pierwotna E określona jest, jako iloczyn energii dostarczanej netto i wskaźników nakładu energii pierwotnej fi (te same wskaźniki dotyczą energii dostarczonej do budynku i wyeksportowanej do systemu). Źródło: opracowanie własne 
Definicje budynku niemal zeroenergetycznego (NZEB) można odnieść do budynku zeroenergetycznego (ZEB). Budynek ZEB to budynek, w którym zużycie energii w ciągu roku przeliczonej na energię końcową (dostarczoną i sprzedaną) wyniesie zero ( tzw. site ZEB) lub też w przeliczeniu na energię pierwotną (source ZEB) w ciągu roku wynosi $0 \mathrm{kWh} /\left(\mathrm{m}^{2} a\right)$ (rys. 14.). Natomiast, gdy system techniczny budynku będzie produkował i eksportował więcej energii, niż zużywa budynek, to wówczas budynek będzie +ZEB (rys. 15.). W budynku niemal zero- energetycznym (nZEB) saldo rozliczeń rocznych energii pierwotnej dostarczonej i energii pierwotnej sprzedanej (wyeksportowanej), zgodnie z nowelizacją dyrektywy EPBD i normą PN-EN ISO 15603: 2008- jest dodatnie, budynek więcej zużywa energii pierwotnej niż sprzedaje. Zasada bilansowania energii pierwotnej dla budynku nZEB przedstawiona została na rys. 16.

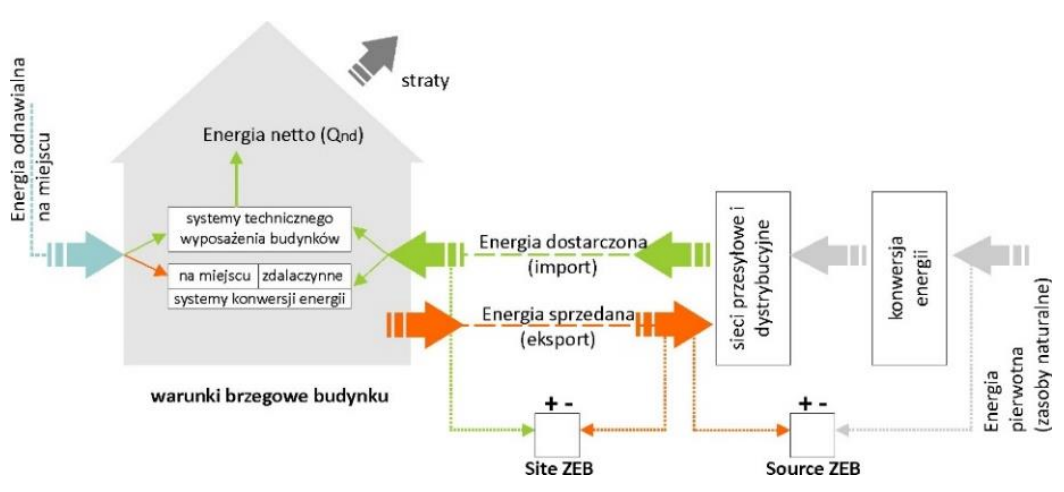

Rys. 14. Zasada bilansowania budynku ZEB oraz nZEB. Żródło: Mańkowski S., Szczechowiak E. 2013

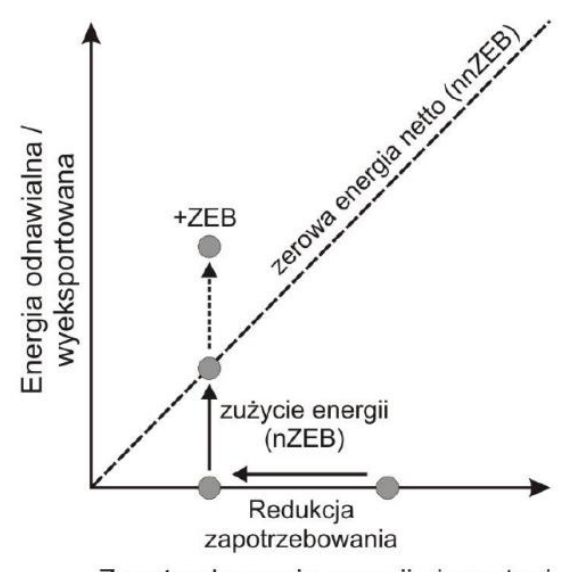

Zapotrzebowanie energii pierwotnej

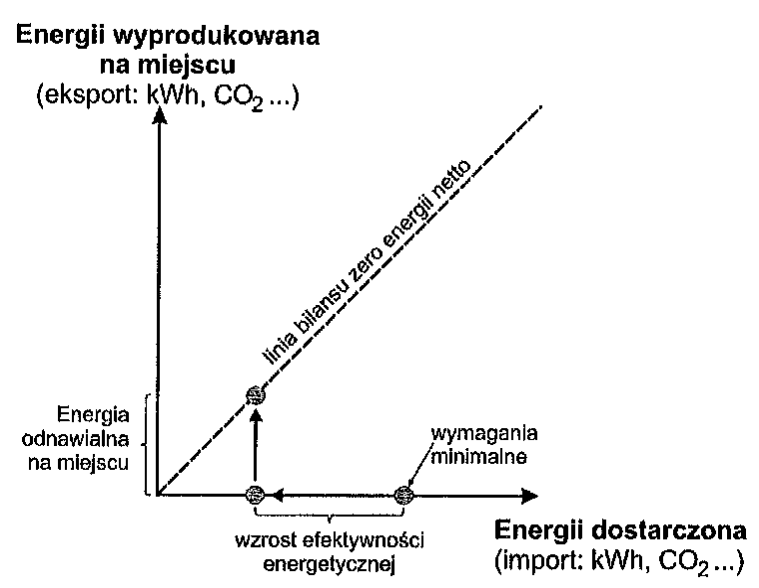

Rys. 16. Zasada bilansowania budynku nZEB. Źródło: Mańkowski S., Szczechowiak E., 2013

Przedmiotowe sformułowania, dyrektywy, definicje czy określenia dotyczące budynku niemal zeroenergetycznego sa opracowywane dla budynków nowoczesnych lub, w mniejszym stopniu, budynków modernizowanych, które są następnie rozliczane $z$ bilansu energetycznego. $Z$ analizy stanu wiedzy Autora wnioskować należy, że nie odnoszą się one do substancji zabytkowej. Stąd Autor stawia pytanie, na które w dalszej części artykułu odpowiada: czy zabytek może być budynkiem niemal zeroenergetycznym? Czy budynek niemal zeroenergetyczny może być zabytkiem? (Rosolski S., 2018) 


\section{ZABYTEK NIEMAL ZEROENERGETYCZNY - KAMIENICA PRZY UL. WRONIECKIEJ 23 W POZNANIU}

Kamienica nr 23 przy ulicy Wronieckiej jest elementem zespołu urbanistycznego staromiejskiej części Poznania. Nie jest wprawdzie zabytkiem pierwszoplanowym, nie jest spektakularnym i nawiedzanym przez tłumy obiektem odgrywającym kluczową rolę dla identyfikacji miasta, ale przecież nie zmienia to faktu, że zawiera cenną substancję, odkrywaną w podjętych badaniach. Przeprowadzona kwerenda ujawniła dane o obiekcie, pokazując dynamiczne transformacje, jakich budynek doświadczył, w tym zniszczenia powstałe podczas II wojny światowej. Wydarzenia te dokumentuje Henryk Kondziela, który już w 1959 roku zebrał materiał ukazujący istotne zmiany dotykające geometrii dachu, formy fasady frontowej, kształtu witryn i wielu innych komponentów, które zostały wystylizowane w powojennym wysiłku odbudowania poznańskiego Starego Miasta. Kamienica przy ul. Wronieckiej stała się elementem tego procesu zmian, a to, co w niej autentyczne, pozostało ukryte głęboko wewnątrz, w piwnicy, w wybranych elementach odsłoniętych w trakcie prac badawczych i dokumentacyjnych. W procesie rozpoznania, kształtowania i definiowania skali ingerencji remontowej poszukiwano elementów pierwotnego zamierzenia budowlanego, diagnozowano nawarstwienia poszczególnych epok, hierarchizowano strukturę i relacje elementów składowych, analizowano wielokierunkową strategię trwałego i solidnego zabezpieczenia obiektu.

Doprowadziło to do działań na polu ochrony i ekspozycji autentyczności substancji zabytkowej. Stąd nowy blask pojawił się za sprawą odkrytego i możliwego do odczytania pierwotnego lica murów wewnątrz kamienicy, jak również, w sposób szczególny, potraktowania elewacji frontowej pierwszego i drugiego piętra jako świadka. Projekt zachowuje pierwszą i drugą kondygnację z wyraźnym współczesnym rysem parteru i kondygnacji poddasza. W ukształtowany $w$ latach sześćdziesiątych XXw. szczyt kamienicy została wkomponowana jego nowa linia z elipsoidalną, przestrzenną formą świadomie przecinająca współczesny gzyms podkreślając tym samym kontekst styku przeszłości z przyszłością. Dla podkreślenia zgodności przyjętych rozwiązań zaprojektowano elewację monochromatyczną w strukturze, materiale i kolorystyce, w tonacji jasnego kwarcu. Kamienica jest również aplikacją modernizacji elewacji w rozwiązaniach dociepleń zewnętrznych i wewnętrznych.

Obiekt od strony technicznej przekształcony został w budynek niemal zero energetyczny (nZEB), co stanowi pionierskie podejście do zabytku, przecierające szlak dla systemu chroniącego substancję skuteczniej, niż kiedykolwiek wcześniej można było to ze względów technicznych uczynić. Wszystkie działania badawcze i inwentaryzacyjne umożliwiły ochronę oraz odsłonięcie starej substancji zabytkowej, która została podkreślona zarówno we wnętrzach jak i na elewacji budynku. Jednocześnie zaadaptowano budynek do nowych funkcji i rozwiązań związanych z energooszczędnością i ochroną środowiska.

Potraktowanie budynku zabytkowego w aspekcie współczesnych wymagań związanych m.in. z obniżaniem energochłonności obiektów i ochroną środowiska było możliwe poprzez:

- Nowe metody badania i dokumentacji;

- Nowe materiały i technologie - nowe rozwiązania techniczne w oparciu o odnawialne źródła energii.

Przystosowanie zabytku do standardu NZEB zostało osiągnięte w oparciu o algorytm projektowania budynków niemal zeroenergetycznych, z uwzględnieniem substancji zabytkowej. Algorytm przedstawiony został na rys. 17.

Nowatorskie podejście do renowacji sprawiło, że zabytkowa kamienica przy ul. Wronieckiej 23 w Poznaniu uzyskała parametry stawiane współczesnym obiektom, spełniając wymagania warunków technicznych obowiązujących w 2021 roku. Wybrane rozwiązania, które zastosowano w budynku, by osiągnąć status niemal zeroenergetycznego obejmują takie elementy, jak:

- Podwyższona ochrona cieplna przegród zewnętrznych budynku:

- Izolacja termiczna elewacji tylnej od strony zewnętrznej - U=0,15 W/m² $\mathrm{K}$

- Izolacja termiczna elewacji frontowej od strony wewnętrznej - dbałość o historyczny detal architektoniczny i dyfuzję pary wodnej $-\mathrm{U}=0,15 \mathrm{~W} / \mathrm{m}^{2} \mathrm{~K}$

- Izolacja termiczna dachu - $\mathrm{U}=0,09 \mathrm{~W} / \mathrm{m}^{2} \mathrm{~K}$ 
- Podwyższona szczelność powietrzna budynku (minimalizacja strat przez infiltrację) $n 50=0,6 \mathrm{l} / \mathrm{h}$ :

- Okna zewnętrzne w ciepłym i szczelnym montażu:

- Okna skrzynkowe drewniane, pięcioszybowe $\mathrm{U}=0,8 \mathrm{~W} / \mathrm{m}^{2} \mathrm{~K}$

- Okna zespolone jednoramowe drewniane, trójszybowe $\mathrm{U}=0,8 \mathrm{~W} / \mathrm{m}^{2} \mathrm{k}$

- Witryny parteru aluminiowe, trójszybowe $\mathrm{U}=0,8 \mathrm{~W} / \mathrm{m}^{2} \mathrm{~K}$

- Okna połaciowe, trójszybowe $\mathrm{U}=0,8 \mathrm{~W} / \mathrm{m}^{2} \mathrm{~K}$

Rys. 17. Algorytm projektowania budynków NZEB (oznaczenia: TC-komfort cieplny, IAQ - jakość powietrza wewnętrznego, EU - ciepło użytkowe dla ogrzewania i wentylacji, HVAC - układ ogrzewania, wentylacji i klimatyzacji, EP - energia pierwotna, Epmax - wskaźnik energii pierwotnej określony dla optymalnego kosztu globalnego dla danej kategorii budynków). Żródło: materiały własne, EKIR 2018

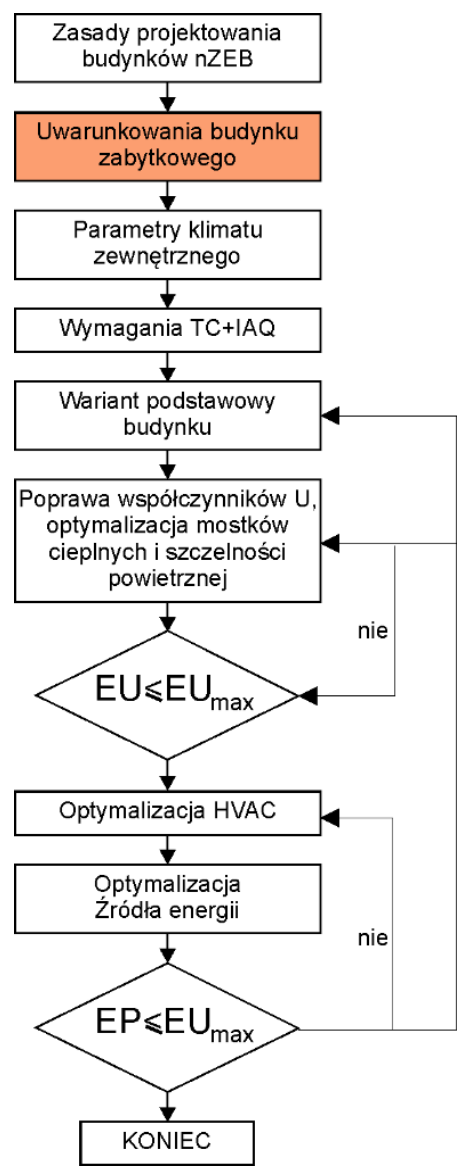

- Okna zewnętrzne zintegrowane - przeszklenia przystosowane do ochrony przed promieniowaniem słonecznym

- Wyrzutnia dachowa wyrzucająca powietrze z dala od czerpni powietrza

- Decentralizacja układów wentylacyjnych / klimatyzacyjnych - dwa rekuperatory podzielone na sekcje kondygnacyjne

- Odzysk ciepła z powietrza wywiewanego - wentylacja mechaniczna z rekuperacją

- Stropy aktywowane termicznie - układ podstawowy stabilizacji termicznej budynku w zimie i w lecie (zintegrowany układ grzewczo / chłodniczy w stropie żelbetowym).

- Schody żelbetowe - akumulacja energetyczna

- Klatka schodowa - naturalne przewietrzanie budynku, komin konwekcyjny

- Pompa ciepła powietrze-woda

- Kolektory słoneczne fotowoltaiczne PV 4KWh do wspomagania zasilania w energię elektryczną (dach) 
- Wykorzystanie skroplin z centrali wentylacyjnej do podlewania roślinności wewnątrz budynku

- Instalacja klimatyzacji dla skrajnych warunków eksploatacyjnych

- Świetliki dachowe w pełni zautomatyzowane i samowystarczalne energetycznie, umożliwiające przewietrzanie obiektu w okresach przejściowych

- Przepona wentylacyjna - naturalne przewietrzanie fundamentów w celu bezinwazyjnego odprowadzenia wilgoci

- Czujniki wilgotności, temperatury, CO2, obecności lotnych związków organicznych, pyłów zawieszonych PM10 i PM2,5 w celu kontroli i prowadzenia badań nad jakością powietrza

- Zintegrowany system informacji kontrolujący parametry obiektu

- Próba zastosowania tynku, który w relacji z iluminacją obniża koszt jej eksploatacji (wg prac laboratoryjnych i realizacyjnych).

Ponadto, na uwagę zasługuje zintegrowany system technicznego wyposażenia w obiekcie jak również jego ekspozycja na tle substancji zabytkowej (ryc. 11, 18).

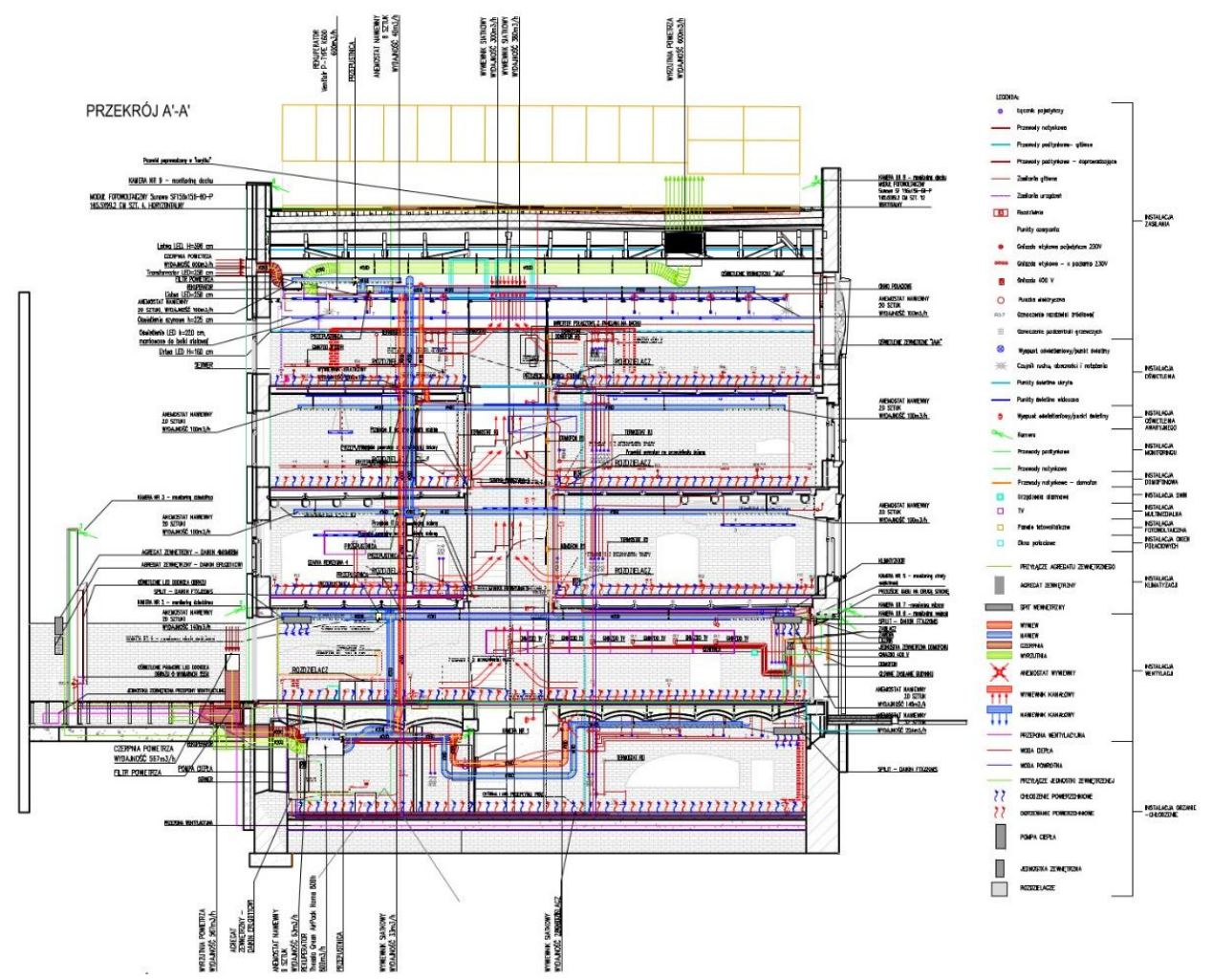

Rys. 18. Zintegrowany system wyposażenia technicznego na Wronieckiej 23. Źródło: Archiwum APP SR Architekt

Uszanowanie historycznych uwarunkowań miejsca oraz potraktowanie kamienicy od strony technicznej umożliwiło uzyskanie parametrów zdefiniowanych dla współczesnych obiektów i spełnienie warunków technicznych określonych w 2021 roku4.

\footnotetext{
${ }^{4}$ Od 2021 roku współczynnik $U$ nie będzie mógł przekroczyć $0,2 \mathrm{~W} / \mathrm{m}^{2} \mathrm{~K}$; okna i drzwi balkonowe: $\mathrm{z} 1,1 \mathrm{~W} / \mathrm{m}^{2} \mathrm{~K}$ na 0,9 $\mathrm{W} / \mathrm{m}^{2} \mathrm{~K}$; okna połaciowe: $\mathrm{z} 1,3 \mathrm{~W} / \mathrm{m}^{2} \mathrm{~K}$ na $1,1 \mathrm{~W} / \mathrm{m}^{2} \mathrm{~K}$; wartość współczynnika Ep (określa on maksymalne roczne zapotrze-
} 
Parametry energetyczne budynku (bilansowanie energii na potrzeby ogrzewania, chłodzenia i wentylacji, ciepłej wody oraz oświetlenia wbudowanego):

- Roczne zapotrzebowanie na energię końcową EK:

- Budynek po renowacji: 17,85-18,95 kWh/(m²a)

- Roczne zapotrzebowanie na energię nieodnawialną pierwotną EP:

- Budynek po renowacji: 53,5-56,8 kWh/(m²a)

- Udział energii odnawialnej w skali roku (kolektory PV): 86-91\%

Charakterystyka energetyczna kamienicy ukazuje dane wyraźnie lepsze of wymagań WT określonych dla nowoczesnych budynków. Roczne zapotrzebowanie na energię nieodnawialną pierwotną EP (energia z sieci + kolektory PV) wynosi:

- Budynek po renowacji: $E P=4,5-7,9 \mathrm{kWh} /\left(\mathrm{m}^{2} \mathrm{a}\right)$

- Wymagania WT 2019/2021: EP $=95,0 \mathrm{kWh} /\left(\mathrm{m}^{2} \mathrm{a}\right)$

- Udział energii odnawialnej: 87-92\% (kolektory PV + PC)

Porównanie energii końcowej i emisji CO2 w budynku po renowacji (BR) w 2020 roku przedstawia poniższa tabela:

Tab.1 Porównanie energii końcowej i emisji CO2 w budynku po renowacji (BR) w 2020 roku. Źródło: materiały własne, EKIR 2018

\begin{tabular}{|l|l|c|c|c|}
\hline Lp. & Wyszczególnienie & $\begin{array}{c}\text { Wymagania EP wg } \\
\text { WT2021 }\end{array}$ & $\begin{array}{c}\text { Zużycie EK wg } \\
\text { WT2021 }\end{array}$ & $\begin{array}{c}\text { Zużycie EK w zabyt- } \\
\text { ku }\end{array}$ \\
\hline 1. & $\begin{array}{l}\text { Ogrzewanie, chłodzenie, wentylacja, } \\
\text { ciepła woda }\left[\mathrm{kWh} /\left(\mathrm{m}^{2} \mathrm{a}\right)\right]\end{array}$ & $\begin{array}{c}45+ \\
25\end{array}$ & 49,5 & $7,85-8,95$ \\
\hline 2. & Oświetlenie wbudowane $\left[\mathrm{kWh} /\left(\mathrm{m}^{2} \mathrm{a}\right)\right]$ & 25 & 8,3 & 10,0 \\
\hline 3. & Razem $\left[\mathrm{kWh} /\left(\mathrm{m}^{2} \mathrm{a}\right)\right]$ & 55,0 & & $17,85-18,95$ \\
\hline 4. & Produkcja własna PV $\left[\mathrm{kWh} /\left(\mathrm{m}^{2} \mathrm{a}\right)\right]$ & & & 16,8 \\
\hline 5. & $\begin{array}{l}\text { Zużycie energii elektrycznej z sieci w } \\
\text { BR }\left[\mathrm{kWh} /\left(\mathrm{m}^{2} \mathrm{a}\right)\right]\end{array}$ & & $\mathbf{2 4 , 6}$ & $1,55-2,65$ \\
\hline 6. & Emisja CO2 $\left[\mathrm{kgCO} /\left(\mathrm{m}^{2} \mathrm{a}\right)\right]$ & $\mathbf{1 , 2 8 - 2 , 1 9}$ \\
\hline
\end{tabular}

W ten sposób zabytkowa kamienica przy ul. Wronieckiej 23 osiągnęła wyniki znacznie przekraczające wymagania:

- Udział energii odnawialnej: 87-92\%

- Emisja CO2 - 5\% standardu!

\section{PODSUMOWANIE}

Kamienica przy ul. Wronieckiej 23 w Poznaniu to substancja zabytkowa wychodząca naprzeciw współczesnym osiągnięciom nowych technologii, posiadająca status jednostki naukowodydaktyczno-badawczo-wdrożeniowej. Interakcja, implementacja oraz poszukiwanie synergii działań na wielu płaszczyznach dziedzin technicznych zwraca uwagę na kontekst związku przeszłości jako zabytku z przyszłością jako zbioru rozwiązań nowych technologii.

bowanie budynku na nieodnawialną energię pierwotną do ogrzewania, wentylacji, chłodzenia, przygotowania ciepłej wody użytkowej oraz oświetlenia). Od 2021 roku współczynnik będzie musiał być obniżony do minimum $70 \mathrm{kWh} / \mathrm{m}^{2} / \mathrm{rok}$. 
Wroniecka 23 to zabytek stanowiący tło, komponent, ograniczenie, kreację i podejście innowacyjne dla nowych technologii, których celem jest poprawa trwałości obiektu i ochrona substancji historycznej skuteczniej niż dotychczas.

Opisywany budynek przybliża zagadnienia dotyczące określenia związku pomiędzy wartością zabytkową a wykorzystaniem współczesnych technologii w procesie przystosowania zabytku do parametrów budynku o niskim zużyciu energetycznym. Jest to możliwe bez znaczącego uszczerbku dla jego substancji zabytkowej i tożsamości oraz poszanowania starej tkanki.

Nowe technologie posłużyły tu jako narzędzia do badania i diagnostyki struktury substancji zabytkowej obiektu. Stanowią również innowacyjne rozwiązania umożliwiające poprawę standardu budynku poprzez wykorzystanie energii odnawialnej, poprawę efektywności energetycznej struktur budowlanych i wyposażenia technicznego, obudowy zewnętrznej i wewnętrznej, by spełnić najwyższe standardy komfortu klimatycznego wewnątrz obiektu z jednoczesnym spełnieniem wymogów związanych z minimalnym kosztem globalnym w cyklu życia budynku LCA. Dlatego też, w celu zobrazowania kondycji budynku, zainstalowano systemy monitoringu, automatycznego sterowania i zarządzania kamienicą. Ich zadaniem jest zapewnienie monitoringu wartości istotnych parametrów środowiskowych i stanów instalacji, integracja urządzeń technologicznych, opomiarowanie zużycia i produkcji energii oraz rejestrowanie, analizowanie i prezentacja danych.

Wroniecka 23 podjęła próbę i wykazała, że możliwe jest dostosowanie zabytku do standardu budynku niemal zeroenergetycznego. Należy tu podkreślić fakt, że obecnie ta zabytkowa kamienica znacznie przewyższa wymagania polskich warunków technicznych na okres po 2020 roku. Wymagania WT'2021 wynoszą 95,0 kWh(m2a), a wyniki uzyskane po renowacji budynku z kolektorami PV wynoszą 4,54-7,89 kWh(m2a). Jest to wynik lepszy o ca. 92-95\% od obowiązujących wymagań.

\section{BIBLIOGRAPHY}

Barełkowski R., Kryteria dobrej architektury. Zasady krytycznej oceny decyzji projektowych., Architektura w ujęciu interdyscyplinarnym, 29-37, Ośrodek Wydawnictw Naukowych, Poznań 2004.

Bonenberg W., Budynek inteligentny - integracja techniki i sztuki, Biuletyn, Inauguracja Roku Akademickiego 1997/1998, Wydawnictwo Politechniki Poznańskiej, Poznań 1997.

Bonenberg W., Dziadosz A., Kapliński O., Cykl życia budynku. Przykłady analizy łącznych kosztów z komentarzami, Człowiek-Ekologia-Architektura, tom 4: Regeneracja architektury. Wydawnictwo Politechniki Poznańskiej, 7-18, Poznań 2017.

Borusiewicz W., Konserwacja zabytków budownictwa murowanego, Wyd. Arkady 1985.

Brodzka J., Ciarkowski B., Konserwacja i kreacja architektury. Jan Tajchman i jego działalność, Wyd. Tako 2015.

Czerner O., Wartość autentyzmu w zabytkach, Ochrona Zabytków. Nr 3, 180-183, 1974.

Dyrektywa 2010/31/ UE Parlamentu Europejskiego z dnia 19 maja 2010r. w sprawie charakterystyki energetycznej budynków.

Krasnowolski B., Doktryny i realizacje konserwatorskie., Wyd. WAM 2011.

Małachowicz E., Konserwacja i rewaloryzacja architektury w środowisku kulturowym. Wyd Politechnika Wrocławska 2007.

Mańkowski S., Szczechowiak E. Strategiczny projekt badawczy pt. „Zintegrowany system zmniejszenia eksploatacyjnej energochłonności budynków”, Zadanie badawcze nr 2 pt. „Opracowanie optymalnych energetycznie typowch rozwiązań strukturalno- materiałowych i instalacyjnych budynków". Tom pierwszy, część B „Podejscie zintegrowane do budynków współczesnych”. Warszawa, Poznań, Wyd. Politechnika Poznańska 2013. 
Norma EN 15603: 2008

Rosolski S., Budynek niemal zeroenergetyczny w aspekcie proekologicznych i prospołecznych uwarunkowań budownictwa zrównoważonego, Człowiek-Ekologia-Architektura, tom 2: Architektura wobec wyzwań zrównoważonego rozwoju. Wydawnictwo Politechniki Poznańskiej, 31-50, Poznań 2016.

Rosolski S., Energooszczędność w obiektach historycznych. Czy zabytek może być budynkiem niemal zeroenergetycznym? Czy budynek niemal zeroenergetyczny może być zabytkiem?, wykład: Europejski Kongres Informacji Renowacyjnej (EKIR), Kraków 2018.

Rosolski S., Energooszczędność w obiektach historycznych. Czy zabytek może być budynkiem niemal zeroenergetycznym? Czy budynek niemal zeroenergetyczny może być zabytkiem?, wykład: Konferencja Naukowa: nowe badania, materiały i technologie w ochronie i konserwacji zabytków., ICOMOS 2019.

Rosolski S., Kamienica przy ul. Wronieckiej 23, Poznań, Renowacje i Zabytki, nr 4(72)2019, 182-185, ISSN 1643-2029.

Rosolski S., Projektowanie architektoniczne a zagadnienia odwrotne. Wyd. Exemplum 2012.

Rosolski S., Regeneracja struktury budynku zabytkowego, Człowiek-Ekologia-Architektura, tom 4: Regeneracja architektury. Wydawnictwo Politechniki Poznańskiej, 101-114, Poznań 2017.

Rosolski S., Szczechowiak E., Rewitalizacja zabytkowej kamienicy śródmiejskiej do standardu niemal zeroenergetycznego, wykład: Konferencja Naukowo-Techniczna, Wałcz 2021.

Rosolski S., Zabytek niemal zeroenergetyczny nZEB. Kamienica Wroniecka 23 w Poznaniu, wykład: Europejski Kongres Informacji Renowacyjnej (EKIR), Kraków 2021.

Rouba, B. Autentyczność i integralność zabytków, Ochrona Zabytków, Nr 4, 37-57, 2008.

Rymaszewski B., Polska ochrona zabytków., Wyd. Scholar 2005.

Szczechowiak E., Rosolski S., Machaty P., Cyrkulacje, nr 64, Kamienica Wroniecka 23 w Poznaniu, lipiec sierpień 2021, 24-25, ISSN 2300-9373.

Szczechowiak, E., Budynki energooszczędne i pasywne, Czysta Energia, 3, 22-26, 2008.

Szczechowiak, E., Efektywność energetyczna budynków. Zeszyty Naukowe Politechniki Gdańskiej. Budownictwo Lądowe nr 58, 25-44, 2006.

Szczechowiak, E., Mróz T., Komfort klimatyczny a projektowanie architektoniczne, Międzynarodowe Seminarium Naukowe nt. Urbanistyczne Instrumenty Promocji Inwestycji, Rokosowo, 1993.

Szczechowiak, E., Nowe tendencje w ograniczaniu zużycia energii cieplnej budynków. Ogrzewnictwo praktyczne, nr 4, 11/95, 1995b.

Szczechowiak, E., Zmiany w budownictwie w aspekcie zrównoważonego rozwoju, 54 Konferencja Naukowa Komitetu Inżynierii Lądowej i Wodnej PAN i Komitetu Nauki PZiTB, Białystok-Krynica, 21-26 września 2008, Zeszyty Naukowe Politechniki Białostockiej 2008.

Szczechowiak. E. IV Forum Budownictwa Energooszczędnego i pasywnego, Budma 2013r., Poznań

Tomaszewski A., Ku nowej filozofii dziedzictwa., Wyd. Międzynarodowe Centrum Kultury 2013.

Ustawa z dnia 23 lipca 2003 r. O ochronie zabytków i opiece nad zabytkami, Dz. U. 2003 Nr 162 poz. 1568.

Ustawa z dnia 7 lipca 1994 r. Prawo budowlane Dz. U. 1994 Nr 89 poz. 414.

Zeidler K., Prawo ochrony zabytków., Wyd. Uniwersytetu Gdańskiego 2014.

\section{AUTHOR'S NOTE}

Author focuses his work and interests on designing NZEB constructions, passive constructions, integrated designs, construction in terms of ecological effectiveness, sustainable development and adaptation of historic facilities to contemporary functions. He is author of the theory of reciprocal aspects in architectural design and creator of a new scientific specialty - architechnology. 


\section{O AUTORZE}

Dorobek naukowy Autora oraz jego zainteresowania własne ukierunkowane są na obszary projektowania budownictwa niemal zeroenergetycznego, pasywnego, projektowania zintegrowanego, budownictwa w aspekcie efektywności ekologicznej i zrównoważonego rozwoju oraz adaptacji budynków zabytkowych do współczesnych form użytkowania. Jest autorem teorii zagadnień odwrotnych w projektowaniu architektonicznym i kreatorem nowej specjalności naukowej - architechnologii.

Contact | Kontakt: slawomir.rosolski@put.poznan.pl 